\title{
CORRELATES OF LIFE EXPECTANCY IN LESS DEVELOPED COUNTRIES
}

\author{
ROBERT N. GROSSE and BARBARA H. PERRY \\ Department of Health Planning and Administration, School of Public Health, University of Michigan, \\ Ann Arbor, MI 48109, U.S.A.
}

\begin{abstract}
Analyses were performed to investigate several hypotheses concerning the multiple determinants of levels of life expectancy in developing countries in recent decades and some possible explanation for the observed variations in amount of gain in life expectancy from the 1950's to the 1970's. The findings were significant. For level of life expectancy the results of this present work conform by and large to results of other scholars in this area, although the present work is unique in that only developing countries were included. From the 1960's to the 1970's there has been a shift in the relative importance of economic indicators and general social indicators in favor of the social indicators. In the period 1960-65 some $70 \%$ of the variation in levels of life expectancy was associated with per capita income and literacy rates in a ratio of about three to two in favor of the economic variable. By 1970 75 the ratio has become six to one in favor of literacy. In addition, the multivariate model showed that the sanitation variables began to appear as significant correlates of levels of life expectancy in the more recent time period, playing a larger role than level of income per capita. Work pursued as part of a separate but concurrent project explored explicitly this three-way interaction between literacy, life expectancy and sanitation.

For change in life expectancy from 1950 through 1970, associations were quite different. Per capita income was not associated with the absolute change in life expectancy, and the associations with literacy were much smaller than earlier observed with level of life expectancy at a point in time. In the multivariate model the primary correlates with change were the sanitation variables and health personnel as represented by population per midwife. Tests for such associations with variations in amount of gain in life expectancy have not been found in other literature and comparison with other findings can therefore not be made directly. The present work suggests that it may be lower skill levels of health manpower and activities in sanitation that are the main correlates in a multivariate model of absolute change in life expectancy.
\end{abstract}

\section{Introduction}

Attempts at international comparisons of levels of health and well-being are fraught with all the complexities of trying to understand any elusive phenomenon. A nation's level of health is the result of many interrelated causes. It may have been reached by methods tangible and intangible, direct and indirect and through multiple levels of social and cultural conditions. Difficulties of definition and interpretation because of the lack of adequate data notwithstanding, in an era of increasing recognition of limited resources worldwide, it becomes ever more important to try to understand the pos- 
sible reasons why levels of well-being may improve in some countries and remain the same or improve much less quickly in others. That life expectancy at birth has risen about ten years in the past twenty in most of the less developed countries does not mean that simply having time elapse will bring about improvements in the mortality and morbidity in these countries which will bring them all to desired levels. Continuing improvement is likely to be retarded if the marginal productivity of some forces drops because some complementary activities do not move in balance. The parallel rises in economic levels, social well-being, and health service investments that took place in the more developed countries may not repeat themselves in any automatic fashion in the less developed countries.

It appears to be useful to try to identify the forces associated with the courses of mortality experience in less developed countries. In this paper we report on statistical correlations recently performed in an effort to understand what factors seem to determine the levels of life expectancy at birth at particular times and changes in those levels over time. It is recognized that what really is desired is a measure of the health of a population. Unfortunately there is no single measure that will encompass all aspects of health of a population. Life expectancy is chosen as the more positive measure of the mortality experience in a country and relatively more reliable for international comparisons than other measures that might have been used such as age and disease specific mortality or morbidity. Life expectancy at two points in time was used, $1960-65$ and 1970-75, the absolute change from the 1950's to the 1970's and additionally the level of infant mortality in 1974.

The following report on the results of the analysis includes first a brief discussion of historical trends and empirical studies, a description of the countries and independent variables used, a section on the indications from zero order correlations, a section on the multivariate model results, and finally discussion and conclusions.

\section{Health Levels - Historical Trends and Relationships}

Since the end of World War II, and probably extending as far back as 1930 , there has been a substantial decline in mortality in the poorer countries of the world. In Table I are shown the levels and changes in life expectancy at birth from the period 1950-55 to $1970-75$ by region of the world. One manifestation of this mortality decline has been labeled the population explosion, in that the large increase in the numbers of people has been associated with drops in deaths, rather than increases in fertility. There has been considerable debate about the causes of the mortality decline; some participants have argued it has been the result of increasing success in the 
TABLE I

Life Expectancy at Birth, 1950-55 to 1970-75

\begin{tabular}{lcccc}
\hline & $1950-55$ & $1970-75$ & $\begin{array}{l}\text { Absolute } \\
\text { Gain } \\
\text { (years) }\end{array}$ \\
\hline Eastern Africa & 34.7 & 43.8 & 9.1 & 26.2 \\
Middle Africa & 35.2 & 41.9 & 6.7 & 19.0 \\
Western Africa & 32.0 & 40.9 & 8.9 & 27.8 \\
Southern Africa & 43.2 & 50.8 & 7.6 & 17.6 \\
Northern Africa & 42.0 & 52.0 & 10.0 & 23.8 \\
Eastern South Asia & 40.4 & 50.6 & 10.2 & 25.2 \\
Middle South Asia & 38.6 & 48.0 & 9.4 & 24.4 \\
Western South Asia & 43.9 & 53.8 & 9.9 & 22.6 \\
China & 45.0 & 61.6 & 16.6 & 36.9 \\
Other East Asia (exc. Japan) & 48.2 & 61.1 & 12.9 & 26.8 \\
Caribbean & 52.9 & 63.1 & 10.2 & 19.3 \\
Middle America & 49.6 & 61.5 & 11.5 & 23.2 \\
Tropical South America & 51.9 & 60.5 & 8.6 & 16.6 \\
& & & & \\
Less developed regions & 41.6 & 52.2 & 10.6 & 25.5 \\
\hline
\end{tabular}

Source: United Nations, Population Studies No. 60, 1977.

application of communicable disease control technologies through public health activities (Stolnitz, 1975); others that it has been the result of general economic improvement, particularly in the elimination of famines and improved nutrition available to the people of the less developed countries (Krishnan, 1975).

The relationship of health status to social and economic well-being has long been recognized, but argument has it that the association between economic levels and health status has weakened in recent decades, with the increasing capacity of social or health programs to affect health. George Stolnitz (1975), in a paper of the 1974 Bucharest World Population Conference, argued:

\footnotetext{
The evidence appears overwhelming that levels of living and life-style can be greatly offset or even dominated by what might be called programmed disease control, defining the last broadly to include all public health programmes, hospital plus all other medical resources, and sanitary facilities. In areas where mortality is especially high, as in Africa and parts of Asia, public health and sanitation are almost surely the main prime movers needed for achieving rapid initial change. In less developed areas with already reduced, but still high mortality, hospital and other medical facilities have tended to become the strategic main factors for further change once public health and sanitation subsystems have come into being. The same has been true of less developed areas which have begun to penetrate current or recent ranges of mortality in developed areas. In all of these cases, the onset of rapid changes, both in mortality and major causes of death, is found to be closely related with programmes instituted by governments, international agencies and other health related institutions.
} 
In their study of Latin American mortality trends, Arriaga and Davis (1969) concluded that after 1930 low and high income countries:

\begin{abstract}
have registered a similar and very rapid increase of life expectancy at birth, regardless of the mortality level already reached. The mortality level and its change - principally the latter can no longer be seen as dependent on economic development. There is no doubt that other factors are at work. Among them, probably the most important is the improvement of public health facilities and medical care.
\end{abstract}

Samuel Preston (1976a) also argues that:

It seems to have been predominantly broad gauged public health programs of insect control, environmental sanitation, health education, and maternal and child health services that transformed the mortality picture in less developed areas.

This generality of improvement in life expectancy is found to pertain to almost all countries of the developing world since 1950. The argument over whether economic growth or social and heal th programs have accounted for the health improvements has by no means been conclusively decided in favor of the health programs. There is evidence in the work of Celeste Smucker (1975) of the importance of socio-economic variables over indicators of access to medical care in improvement in mortality levels.

It is puzzling to accept the stated role of health services as the transforming factor in a general trend insofar as there have been substantial differences in the resources devoted to public health programs among developing countries, often with very similar health status results. This alone implies little relationship between results and expenditures. Also there are continual reminders from WHO and developing countries that governmental health programs have been concentrated on a relatively small portion of the population, usually the urban elite.

\title{
III. Empirical Studies of Life Expectancy and Socio-Economic Well-Being
}

Studies that have been reviewed show mixed results for answers to the question of what has been most associated with the increases in levels of life expectancy in recent decades and throughout the twentieth century. Simple correlations performed on data available by WHO show high correlations between such measures as medical density, per capita income, and bed/population ratio with life expectancy at birth for sixty-eight countries (Gilliand and Galland, 1977). While warning about reservations in the quality of the data, the data nevertheless support recognition that the relationships vary greatly in magnitude between richer and poorer countries.

In a most thorough multi-variate study by Preston (1976a), the change in influence of economic factors was investigated. His findings showed that 
from the period of the 1930's to the 1960's the relationships between income level and life expectancy have taken an upward shift, that is that there remains an upward slope to the relationship, but that by the 1960's comparable attainment in level of life expectancy cost approximately one-third more than the same level in the 1930's. In terms of multivariate analysis, Preston suggested in his early work that literacy was probably not a major contributor to levels of life expectancy, but in a separate study (1976b) he finds that indeed literacy does play a major explanatory role. The importance of education levels has also been shown to be the surest correlate of health in a recent study by Fuchs on post-industrial nations (1979).

All of these studies, however, used a group of countries as the base which included developed as well as developing countries. Findings show, as referenced above in the WHO report and in the work of Preston, that relationships differ for countries based on their levels of income or other measures of development. This is represented by the often used logarithmic transformation when using income and comparing levels of life expectancy Fig. 1 from the work of Preston illustrates this.

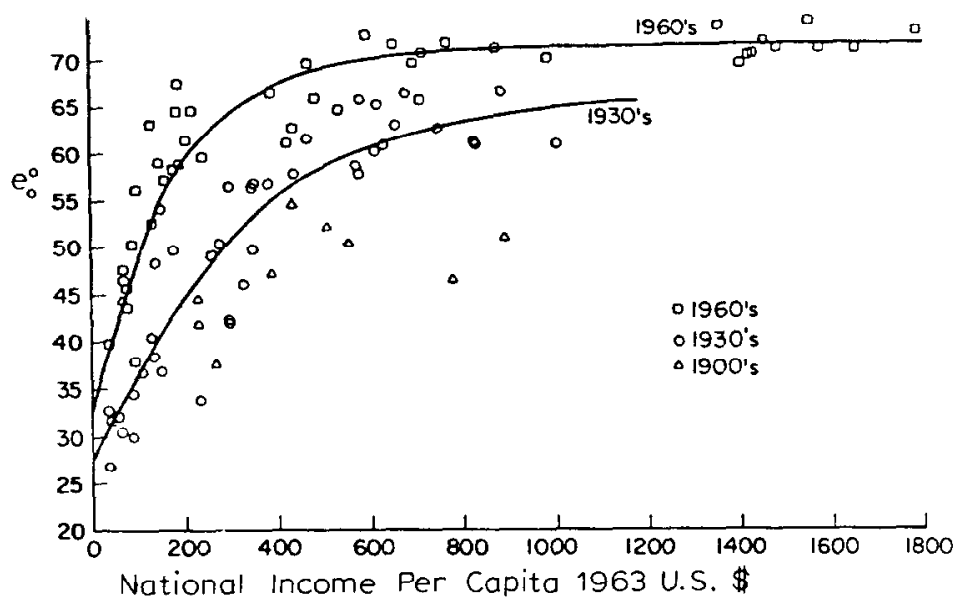

Fig. 1. Relationship between life expectancy at birth (e) and per capita income for nations in the 1900's, 1930's, and 1960's (Preston, 1976b).

Other measures of level of health have also been analyzed for their associations with various socio-economic indicators. In a study of infant and childhood mortality in four developing countries by Sloan (1971), female literacy and nutrition were shown to have definite impact. Sanitation variables and variables that characterize the housing stock of the region were found to explain none of the variation in mortality rates.

For the present study, to try to maintain some homogeneity in countries represented, an attempt was made to analyze only developing countries. U.S., Canada, Japan, Australia, New Zealand and all of Europe were excluded. 


\section{Data on Ninety Developing Countries}

\section{The Dependent Variables:}

The data used for the present analysis were assembled from a number of sources [1]. There was at least some information on each of 140 nations classified as developing countries. A distinction was made between those countries above or below population of one million, with those countries under population one million eliminated from the correlation analysis. By including only countries larger than one million population it was hoped that the possible overrepresentation of atypical situations would be avoided. Appendix $I$ lists the ninety countries included in the current study and their levels on the five proxy measures for level of health. The mean life expectancy for the three periods of time 1950's, 1960's, and 1970's is 42,47 , and 51 years respectively, with a range in the 1950's of from 30 years in Angola to 66 years in Uruguay. By the 1970's, the range became the low of 36 in Bangladesh to the high of 72 in Puerto Rico. Adequate numbers of observations for infant mortality were available only for 1974, and showed an average value of 117 , a range of 45 in Sri Lanka and a reported 17 in Singapore to a high of 200 in Angola.

These five indicators were taken as dependent variables and analyzed, both singly and using multivariate techniques, to find clues for the major areas of contribution to levels of health in these developing countries.

\section{Five Groups of Independent Variables:}

Over 200 measures were available for use as independent variables. These covered a broad range of activities which can be hypothesized to influence the health of a country, some directly, others indirectly. Since the ultimate aim for this, and probably most studies of correlates of levels of health, is to assist in eventual policy decisions among alternative and often competing projects, it was felt useful to group the numerous independent variables into familiar groups of broad categories. They were grouped and analyzed as five interacting areas. These included three health input groups (health expenditures, health personnel and facilities, and sanitation activities), and two general social well-being categories (economic level indicators, and social and educational status measures). A general definition of the scope of each group is:

Sanitation (power and utilities usage and availability).

Health expenditures (including various pharmaceutical imports).

Health personnel and facilities (health manpower, hospitals, health centers).

Economic indicators (revenues, expenditures, employment, GNP/capita, exports and imports, income distribution). 
Social indicators (includes literacy, nutrition, transportation and communication).

Appendix II lists all the independent variables considered, grouped into five broad categories.

\section{Zero Order Correlations}

For many years there has been argument over whether economic growth or social and health programs accounted for the large gains in life expectancy that were observed in developing countries. The most accepted hypothesis that economic level is losing its historic power to determine levels of mortality - was explored, and analyses were performed to determine the relative contributions of those potentially relevant factors about which we could secure information.

Of initial interest was the relationship between economic level alone with level of life expectancy and with change in life expectancy. Simple zeroorder or bivariate correlations demonstrated that in developing countries for the data we used, there was a strong and significant correlation between per capita income and level of life expectancy, but that there was no correlation between absolute changes in life expectancy and level of income per capita.

Some of the variables examined and their correlation are listed in Table II. The column headed " $r$ " notes the correlation coefficient, and " $\mathrm{r}$ " the proportion of variation explained.

TABLE II

Zero Order Correlations Between Income and Life Expectancy

\begin{tabular}{|c|c|c|c|c|}
\hline Independent Variable & Dependent Variable & $\mathrm{r}$ & $r^{2}$ & Significance Level \\
\hline Per capita income 1960 & $\begin{array}{l}\text { Life expectancy at birth } \\
\quad 1970-75\end{array}$ & 0.72 & 0.52 & $\mathrm{p}<0.01$ \\
\hline Per capita income 1970 & $\begin{array}{l}\text { Life expectancy at birth } \\
\quad 1970-75\end{array}$ & 0.66 & 0.44 & $\mathrm{p}<0.01$ \\
\hline Per capita income 1960 & $\begin{array}{l}\text { Life expectancy at birth } \\
\quad 1960-65\end{array}$ & 0.75 & 0.56 & $\mathrm{p}<0.01$ \\
\hline Log of per capita income 1960 & $\begin{array}{l}\text { Life expectancy at birth } \\
\quad 1960-65\end{array}$ & 0.79 & 0.63 & $\mathrm{p}<0.01$ \\
\hline Log of per capita income 1970 & $\begin{array}{l}\text { Life expectancy at birth } \\
\quad 1970-75\end{array}$ & 0.77 & 0.59 & $\mathrm{p}<0.01$ \\
\hline Per capita income 1960 & $\begin{array}{r}\text { Change in life expectancy } \\
1950-55 \text { to } 1970-75\end{array}$ & -0.15 & 0.02 & N.S. \\
\hline Per capita income 1970 & $\begin{array}{r}\text { Change in life expectancy } \\
1950-55 \text { to } 1970-75\end{array}$ & 0.02 & 0.004 & N.S. \\
\hline
\end{tabular}


Percentage changes in life expectancy and percentage changes in income were also compared. There was a significant negative correlation between level of income and percent of change in life expectancy, but not between percent change in income and percent change in life expectancy.

From these correlations, we could conclude that levels of mortality at any one time are related to average levels of income, but that variations in changes in mortality over time are not.

The logarithms of income per capita were used to express the curvilinear shape of its relationship to life expectancy. That is, as higher incomes and life expectancies are examined, the ratio of income to life expectancy becomes less (a flattening of the curve on arithmetic scale). These findings conform to the suggestions of students of mortality. A further investigation was performed to examine more closely the changes in the influence of income on level of life expectancy.

A comparison of the regression lines between life expectancy in 1960 and in 1970 as compared to income per capita (in 1970 U.S. dollars) is shown in Fig. 2. The slopes of the lines are different, with that for 1960 being somewhat steeper. This might indicate that in 1970 increases in life expectancy as a function of economic level required higher economic level per year added than in 1960. In 1960-65, ten years of additional life expectancy at birth "required" a gain of $\$ 300$ per capita. For $1970-75$, a gain of ten years "required" a rise of $\$ 500$ per capita, a $60 \%$ increase.

While there is a very strong relationship between levels of life expectancy and income per capita, other variables are also associated with life expectancy.

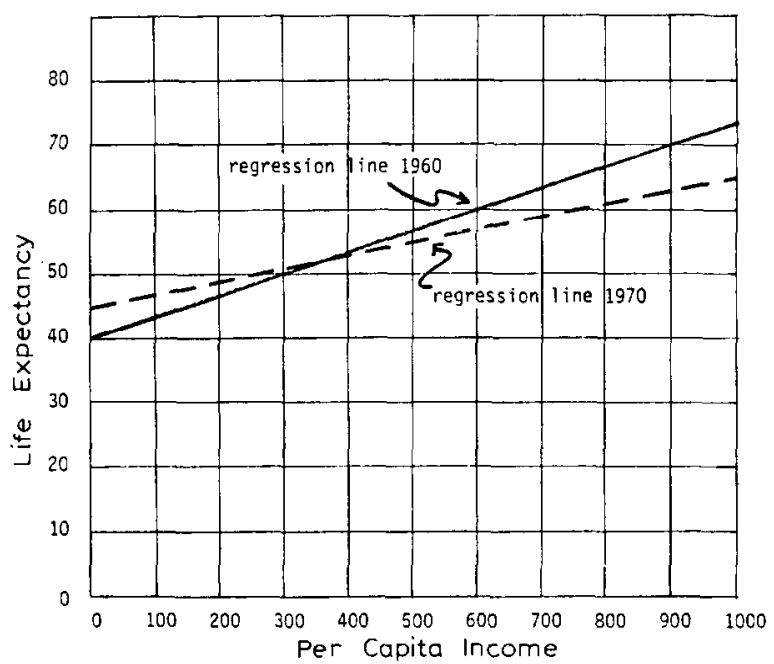

Fig. 2. Life expectancy at birth vs. per capita national income (1970 U.S. \$). 
Simple correlations with variables from each of the five groups showed in fact that levels of life expectancy are correlated with a number of factors. Amongst the group of health expenditure variables several indicators were correlated with health measures, but in general not very highly. The total amount of cleansing agent imports displayed a correlation of between 0.62 and 0.65 with level of life expectancy in each of the three time periods, but no correlation with the absolute amount of change in life expectancy. The amount of pharmaceutical goods imported other than medicaments was associated with the gain in life expectancy, with $r=0.33$. Since these trade data are gathered in different years, all that can really be said is that a positive association is probably affected by activities associated with higher availability of cleaning products.

The association with per capita health expenditures was less strong with correlation coefficients of between 0.36 and 0.41 with level of life expectancy and no significant correlation with amount of change in level of life expectancy over time. Level of total health expenditure also showed positive correlation with level of life expectancy but to a lesser degree $(r=0.21$ for life expectancy in the 1950's, and 0.28 for life expectancy in the 1970's). Also, while per capita health expenditure showed no correlation with change in life expectancy, the amount of total health expenditure did, with a correlation of $r=0.31$.

With the group of health facilities and health personnel variables, the measures of population per general hospital bed had significant correlations with life expectancy, in the order of 0.5 to 0.6 . Correlations with population per physician were also significant, ranging from 0.6 to 0.7 . A somewhat surprising observation was the correlation observed between population per midwife and change in life expectancy from the 1950's to the 1970 's. This was -0.47 using the 1960 figures, and -0.48 using the 1970 figures. This was of the same magnitude as correlations between population per physician in 1960 and $1970,-0.47$ and -0.44 respectively.

The utilities and sanitation variables showed very high correlations with levels of life expectancy. For example, correlation between level of life expectancy in the 1970's and the percent of urban population with household public water taps was 0.72 . The percent of urban total water coverage, tap or standpipe, in 1975 had a positive correlation with gain in life expectancy for $1950-55$ to $1970-75$, of $r=0.31$.

Amongst the social indication variables, as is expected, all are positively correlated with level of life expectancy, but none so highly as the schooling and literacy measures, with correlations as high as 0.88 . Per annum growth rate in food demand showed positive correlation with levels of both life expectancy and absolute change, but not high enough to be more significant than the associations observed with literacy and schooling indicators. A 
most curious observation for the nutrition components of social well-being was their general pattern of positive correlation with levels of life expectancy, and yet negative correlation with changes over time. This seems contrary to what logic would predict.

Plot diagrams for some of the more interesting bivariate regressions are shown in the following charts, namely the effects of some of the health manpower and social indicators singly on changes and levels of the health measures. To ask questions about the relative magnitude of all these different correlates of life expectancy requires their joint consideration in a multivariate model. The next section addresses this issue.

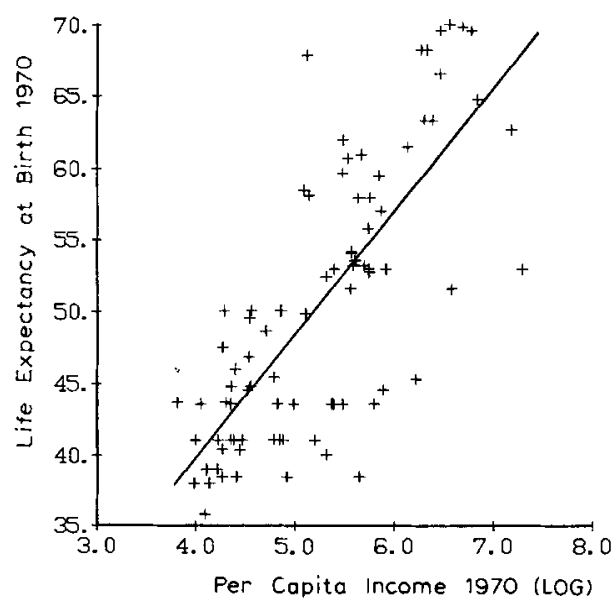

Fig. 3.

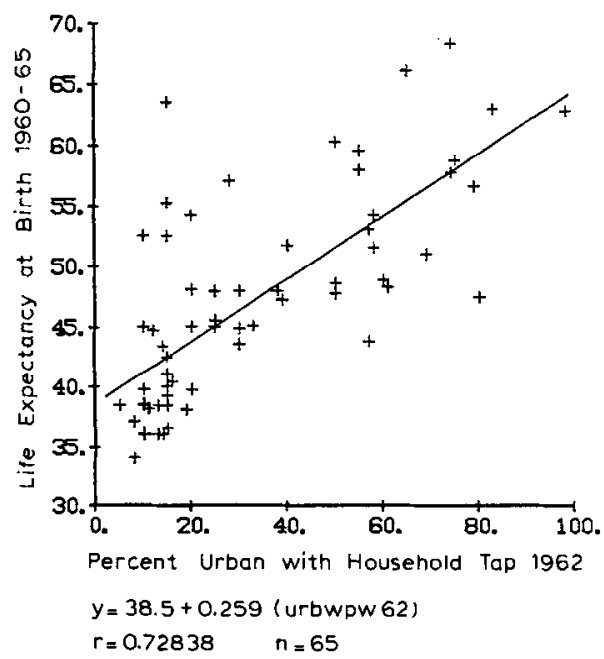

Fig. 5 .

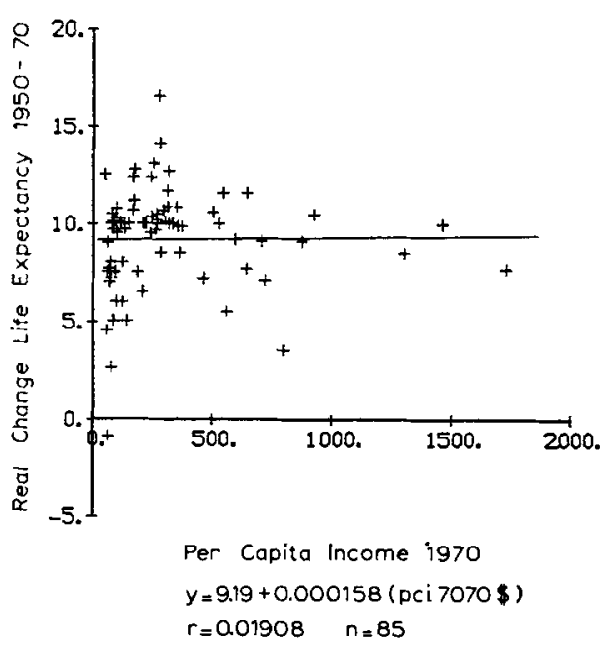

Fig. 4.

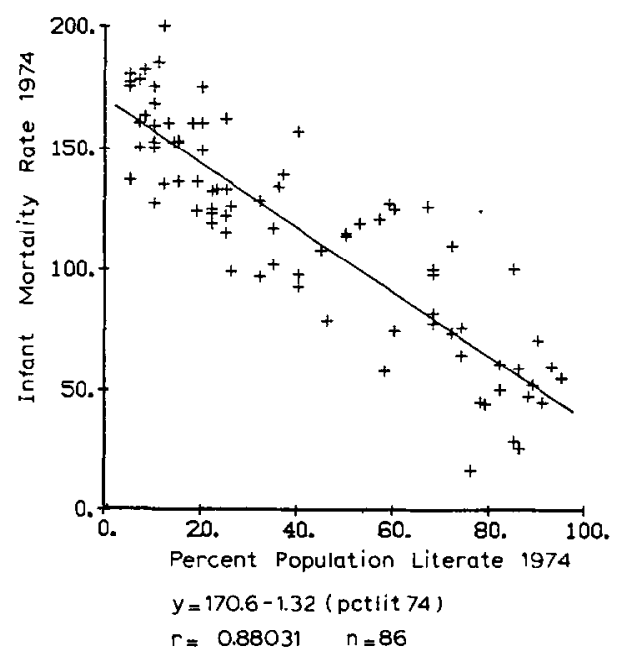

Fig. 6. 


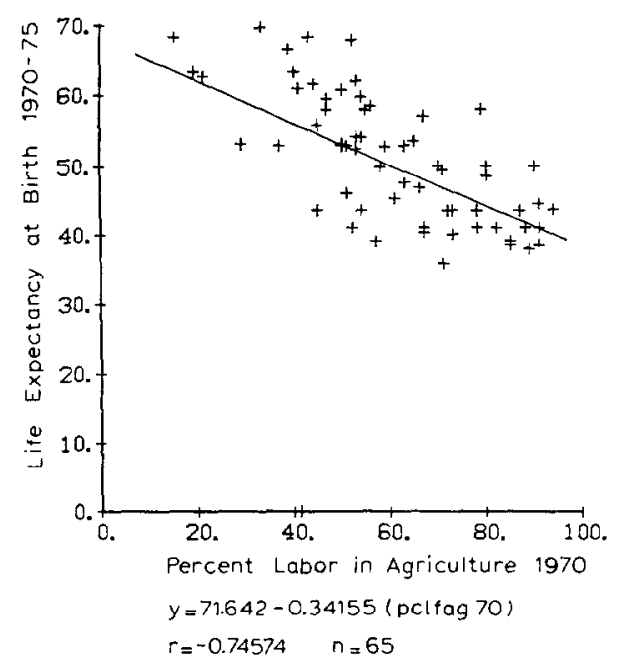

Fig. 7.

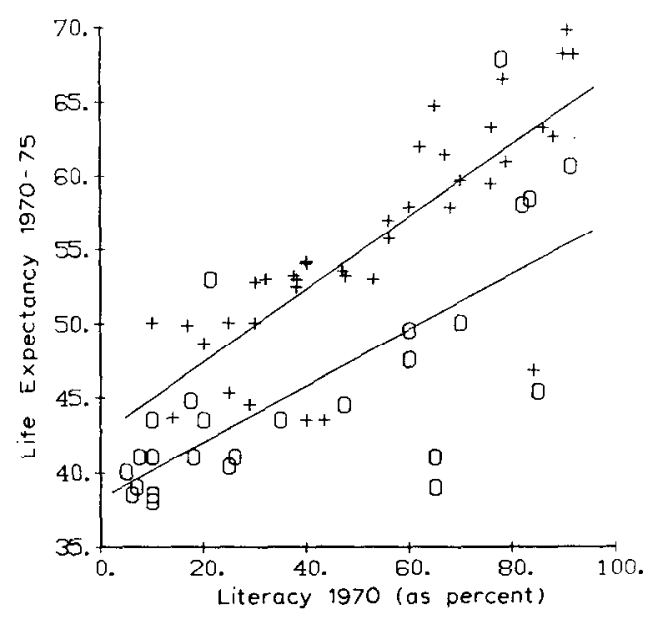

$+=$ countries with high levels* of sanitation

$u=$ countries with low levels ${ }^{\star}$ of sanitation

*High: \% Urban total water coverage $>55 \%$; Low: \% Urban total water coverage $\leqslant 55 \%$.

Fig. 9. Interaction between literacy, life expectancy, and level of sanitation.

Source: Hillel Shuval, Robert Tilden, and Robert Grosse, "The Health Benefits of Sanitation Investments: A Threshold-Saturation Theory," The University of Michigan, School of Public Health, May 1979.

\section{Multiple Regression Analysis}

With some understanding that there are problems with the very measures we wish to associate with one another, and for the time being accepting that the U.N. measures of life expectancy are reasonable estimates, the major measurement errors are in the limited numbers of observations, for the 
same country, of the many variables of interest. We have attempted therefore to include the maximum number of countries at each step of the analyses with the intent that the final model will contain observations for as many countries as possible.

The multivariate analysis was done by first selecting those variables which had the highest zero order correlations with significance levels of $P \leqslant 0.05$ when compared with the individual health indicators, and then performing a two level process of stepwise multiple regression. The most significant correlates within each of the five categories of explanatory variables were selected and the strongest correlates of all those five categories were then combined to show the relative importance of sanitation, health expenditures, health personnel and facilities, economic and social indicators in the presence of the other explanatory variables in terms of their associations with levels of expectancy, with changes in levels of life expectancy over time, and with infant mortality rates.

Tables III through VI illustrate the process by which representative proxies for each of the five categories of variables were selected. These tables show the results of the stepwise regressions. The starred variables are the resulting selections for the five intra-group analyses. In some cases merely combining these five groups of variables as they were selected provided a very small number of countries for which all of these data were available. Where this was the case, subsets of variables were combined (indicated by $\square$ and \#) to provide a larger number of observations for the final regression equations. An explanation of each final result follows.

\section{A. LEVEL OF LIFE EXPECTANCY IN 1960-65 AND IN 1970-75}

For level of life expectancy in the 1960-65 period, in the forty-nine countries which had recorded information on the five selected sanitation variables (percent of population with access to electricity plus the four water supply indicators), once the effects of the three starred variables (those representing access to electricity, percent with household taps and percent increase in urban access to standpipes) were accounted for in the regression model, no additional explanatory power then came from any of the remaining two sanitation indicators: total urban water coverage or urban access to standpipes. This is not to say that the latter two variables are insignificant as far as their impact on life expectancy is concerned. It is rather to say first, that they most definitely do have relationships with life expectancy (this was shown by their significant zero order correlations), but second, that the direct relationship may well be through other variables with which they are also related.

The combination of electricity, urban household taps, and percentage 


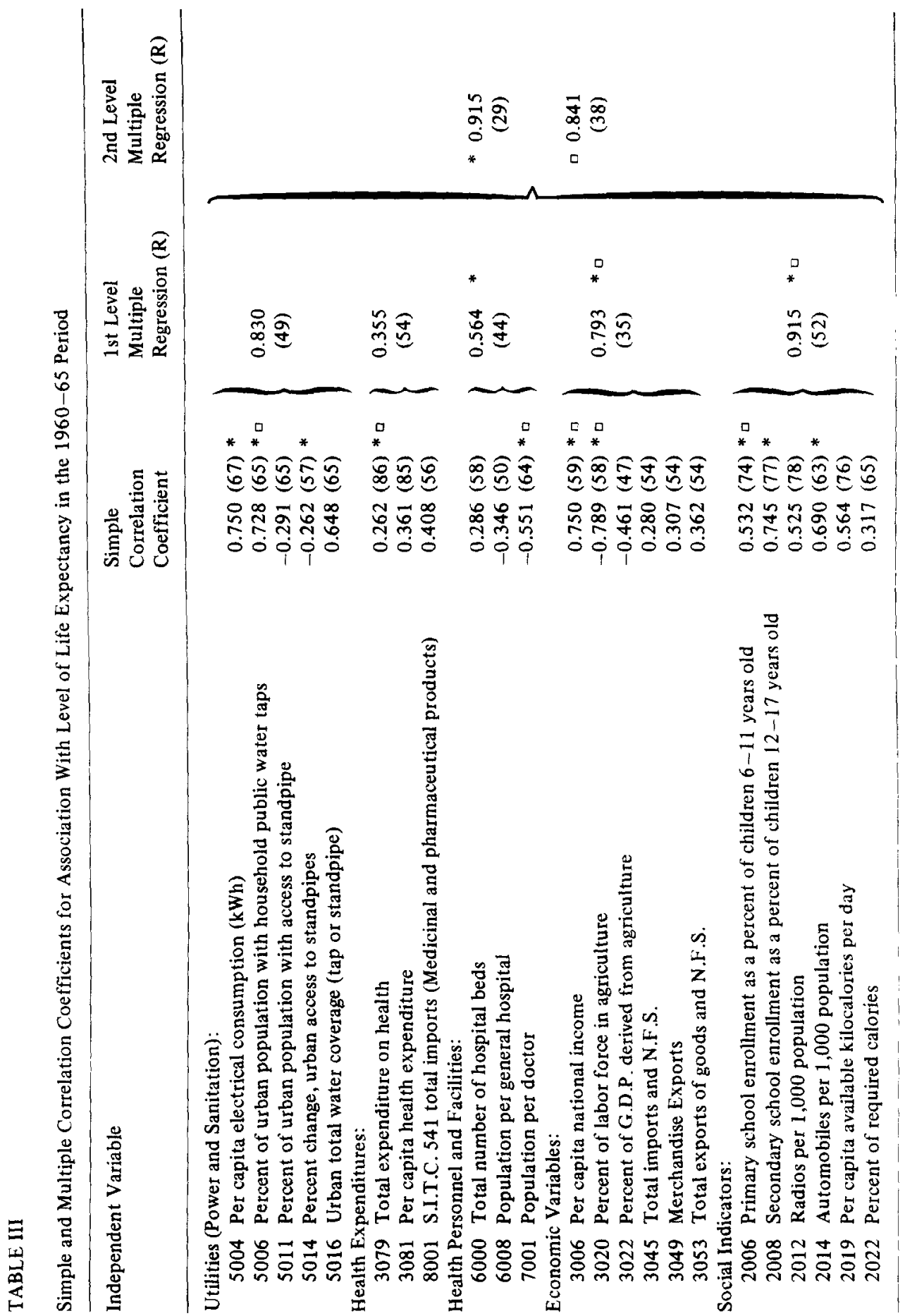




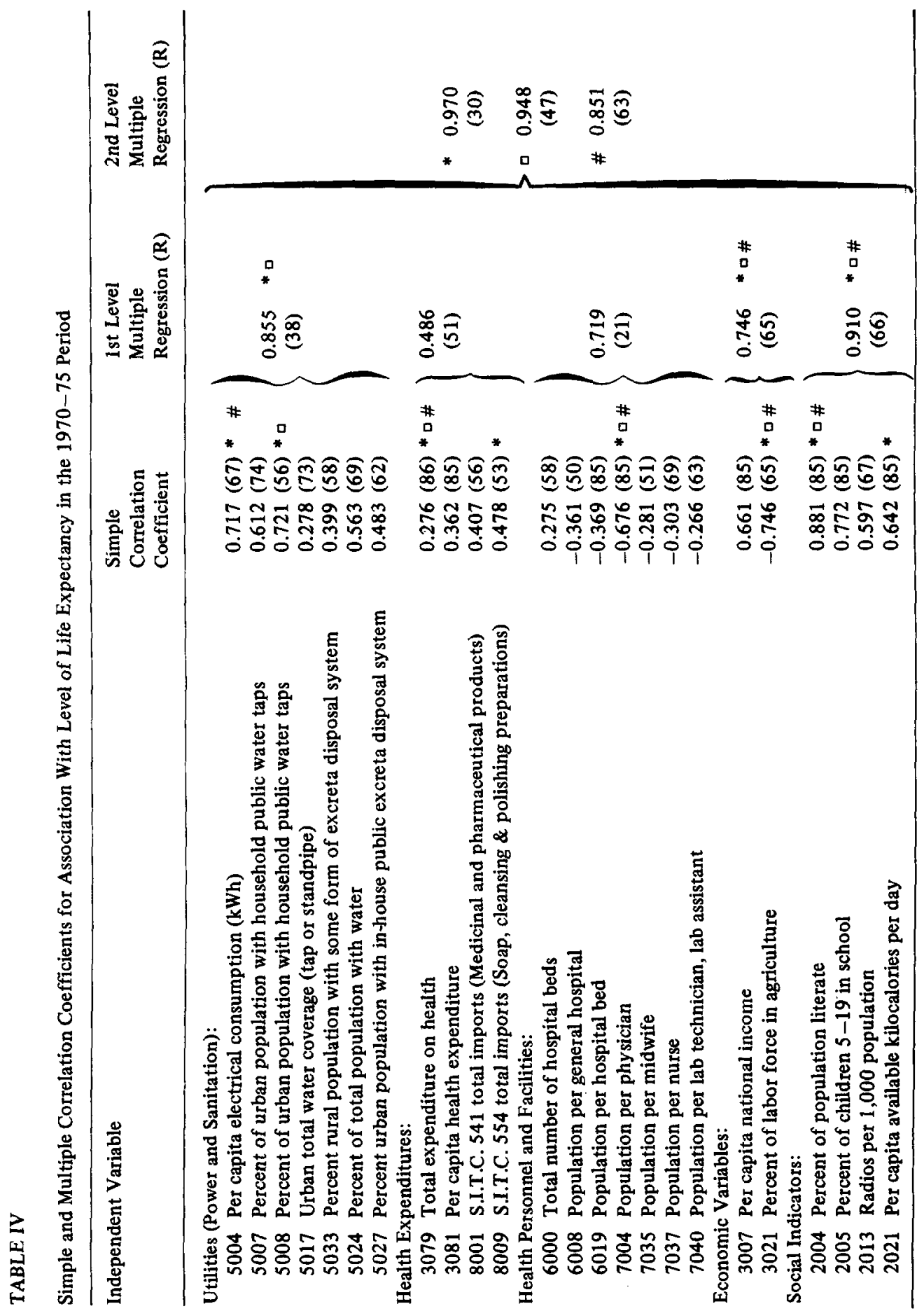


increase in standpipes yielded a multiple correlation coefficient $(\mathrm{r})$ of 0.83 , and thus in the absence of any of the variables from the other four groups, these were associated with $70 \%\left(\mathrm{r}^{2}\right)$ of the variation in life expectancy in 1960-65. Because of this, subsequent selection of sanitation proxies came only from this group of three, and in fact a final stepwise regression was performed only with the urban house tap variable consistent with our efforts to recapture as many countries in the final regression as possible. A similar process was performed for each of the other four categories of independent variables. The final regression model selected for level of life expectancy in 1960 is shown below.

Using as the model for determinants of life expectancy in 1960:

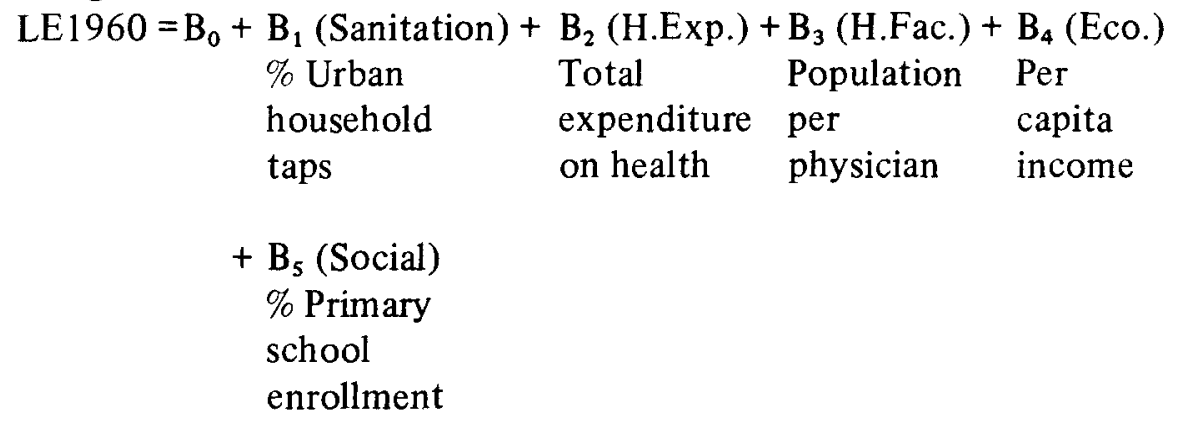

the stepwise regression results were

$$
\begin{aligned}
& \text { LE1960 }=35.36+\quad(\text { Sanitation })+(\text { H.Exp. })+(\text { H.Fac. }) \\
& {[2.000,17.7]^{2} \text { n.s. n.s. n.s. }} \\
& +0.027(\text { Eco. })+0.126 \text { (Social) } \\
& {[0.0035,7.58][0.0248,5.07]} \\
& \mathrm{n}=38 \\
& \mathrm{R}^{2} \text { at first step } \quad=0.49 \\
& \mathrm{R}^{2} \text { at final step } \quad=0.71(\mathrm{~F}=42.4, \mathrm{p}=0.001 \text {, s.e. }=4.64) \\
& \text { partial } \mathrm{r}^{2} \text { econ-social }=0.62 \\
& \text { partial } \mathrm{r}^{2} \text { social-econ }=0.42
\end{aligned}
$$

As explanations of level of life expectancy in the period 1960-65, the economic (as represented by per capita national income) and social indicators (as indicated by schooling) predominate as the primary correlates. After these were added in stepwise fashion to the multiple regression model for life expectancy for the thirty eight countries, no additional explanatory force could be gained by the sanitation, health expenditures, and health personnel and facilities variables. That is not to say these other variables are not correlated, or indeed important in life expectancy. It means that due to the structure of social and governmental systems, the primary, or 
most significant route to life expectancy improvement may have been first by way of improvements in social and economic patterns. It is no coincidence that with these improvements come changes in sanitation, health expenditures and availability of health personnel and facilities. The partial correlation coefficients further show that in this period the economic variable was a stronger correlate than the social variable considering each in the presence of the other.

In 1970-75, the impact of economic variables has diminished, and sanitation plays a larger role in the presence of the other variables (Table IV). It is important to recognize that changes in these areas alone, however, may not bring about the desired or expected changes in life expectancy. The model for determinants of life expectancy in the 1970-75 period gave the following result:

$$
\begin{aligned}
& \text { LE1970 }=B_{0}+B_{1} \text { (Sanitation) }+B_{2} \text { (H.Exp.) }+B_{3} \text { (H.Fac.) } \\
& \% \text { urban Total Population } \\
& \text { household expenditure per } \\
& \text { taps on health physician } \\
& \begin{array}{l}
+\mathrm{B}_{4}(\text { Eco. })+\underset{\mathrm{B}_{5}(\text { Social })}{\% \text { labor } \% \text { literate }} \\
\text { force in } \\
\text { agriculture }
\end{array}
\end{aligned}
$$

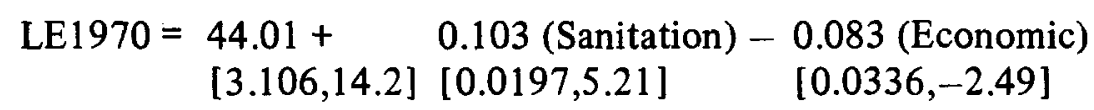$$
+0.180 \text { (Social) }
$$$$
[0.0231,7.81]
$$$$
\mathrm{n}=47
$$$$
\mathrm{R}^{2} \text { at first step (social) } \quad=0.78
$$$$
\mathrm{R}^{2} \text { at second step (social, sani.) } \quad=0.88
$$$$
\mathrm{R}^{2} \text { at final step (social, sani., econ.) }=0.90(F=126.97, p=0.000 \text {, }
$$$$
\text { s.e. }=2.99 \text { ) }
$$

partial $\mathrm{r}^{2}$ (soc., sani., econ.) $\quad=0.59$

partial $\mathrm{r}^{2}$ (sani., econ., soc.) $\quad=0.39$

partial $\mathrm{r}^{2}$ (econ., sani., soc.) $\quad=0.13$

A total of $90 \%$ of the variation in life expectancy in the period 1970-75 is explained by the three variables literacy, urban water availability, and percent of labor force in agriculture, in that order of importance. After the inclusion of these three indicators, health expenditures and health facilities and personnel variables did not add to the amount of variation explained. Total expenditure on health was used as an independent variable rather 
than per capita because for the fifty-one countries with all four items listed under health expenditures in Table IV, total health expenditure was a stronger correlate. Analysis with per capita expenditure did not change the result of the final model. Percent of labor force in agriculture was used as the economic indicator because it was a stronger correlate than per capita income. Had per capita income been used, the contribution of the economic indicator would have been even less.

If we modify the model slightly by substituting electrical consumption for percent of urban population with public water taps as the sanitation and utilities variable, at the cost of using a slightly less powerful sanitation component we gain sixteen additional countries in the sample. The multivariate results then become:

$$
\begin{aligned}
& \text { LE1970 }=49.83-\quad 0.00009 \text { (Health Facilities) } \\
& {[2.679,18.60][0.000037,-2.35]} \\
& -0.106 \text { (Economic) }+0.215 \text { (Social) } \\
& {[0.0332,-3.18] \quad[0.0241,8.94]} \\
& \mathrm{n}=63 \\
& \mathrm{R}^{2} \text { at first step (social) } \quad=0.80 \\
& \mathrm{R}^{2} \text { at second step (social + econ.) } \quad=0.84 \\
& \mathrm{R}^{2} \text { at final step (social + econ. + H.Fac.) }=0.86(\mathrm{~F}=118.02, \mathrm{p}=0.000 \text {, } \\
& \text { partial } \mathrm{r}^{2} \text { (social-econ., H.Fac.) } \quad=0.58 \\
& \text { partial } \mathrm{r}^{2} \text { (econ.-social, H.Fac.) } \quad=0.15 \\
& \text { partial } \mathrm{r}^{2} \text { (H.Fac.-social, econ.) } \quad=0.08 \\
& \text { s.e. }=3.63 \text { ) }
\end{aligned}
$$

Still literacy dominates, with the economic indicator and health personnel variables playing significant though smaller roles.

The significant correlation of the sanitation variable with level of life expectancy in 1970-75 prompted a further look at the three-way interrelationship between sanitation, literacy, and level of life expectancy. Figure 9 shows how controlling for literacy can show the effect of higher versus lower sanitation investments with regard to associated levels of health.

\section{B. ABSOLUTE CHANGE IN LIFE EXPECTANCY FROM 1950 TO 1970}

In a similar manner, health personnel (as represented by population per midwife) and sanitation indicators (as represented by urban water coverage) dominate as explanatory variables for variations in changes in life expectancy from 1950 to 1970 , though able to explain a much smaller percentage of the variation, $28 \%$ and $10 \%$ respectively. It is true that most of the variation in change in life expectancy remains unexplained by variables included in the multivariate model, but what is also true is that a significant part of 


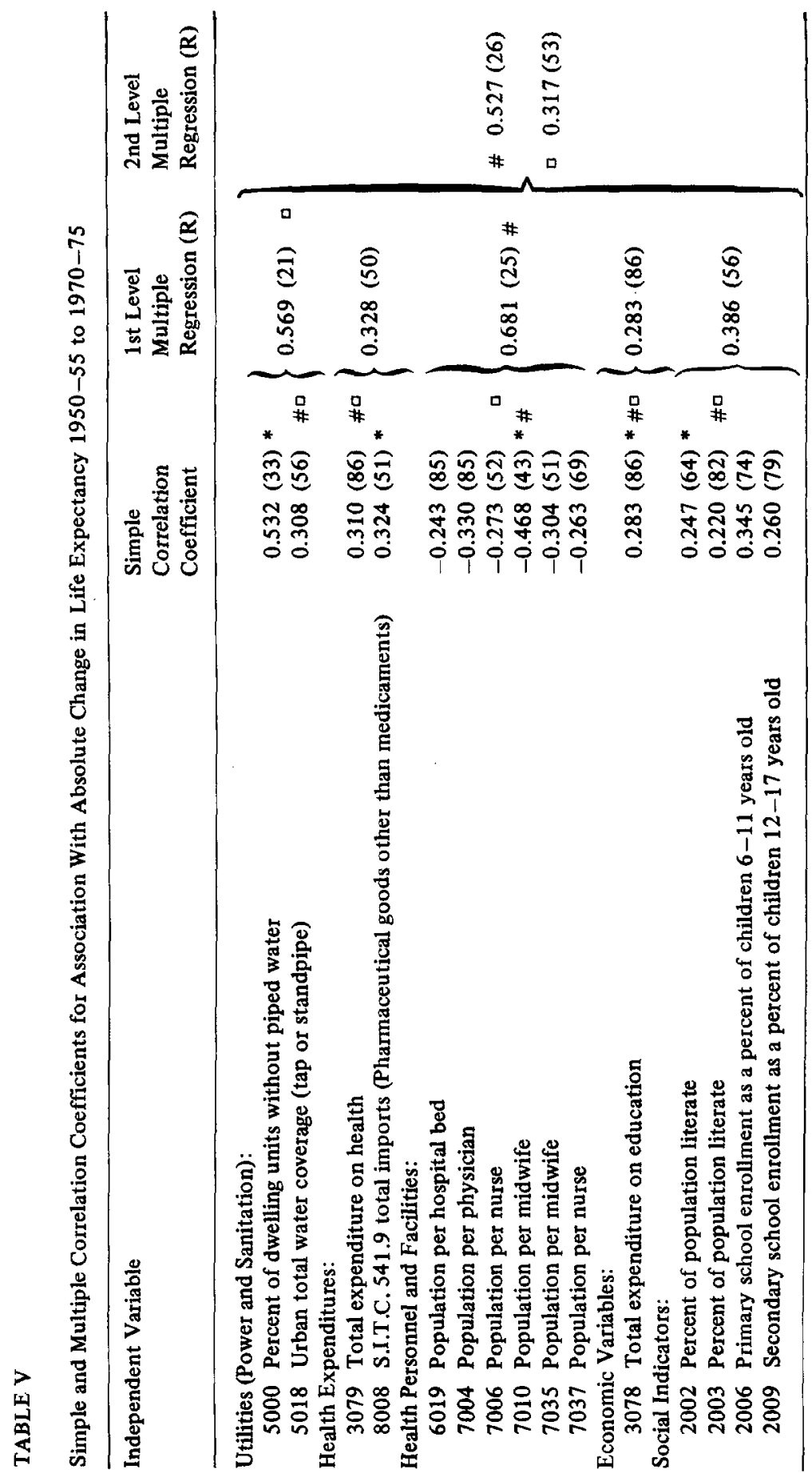


the variation is correlated with the sanitation indicator and the lower level health manpower indicator, population per midwife. Per capita health expenditures were not at all correlated, nor is level of per capita national income, and once the sanitation or health personnel variable is in the model no additional explanatory power comes from the already weak representatives of the other variables.

The first model for change in life expectancy is:

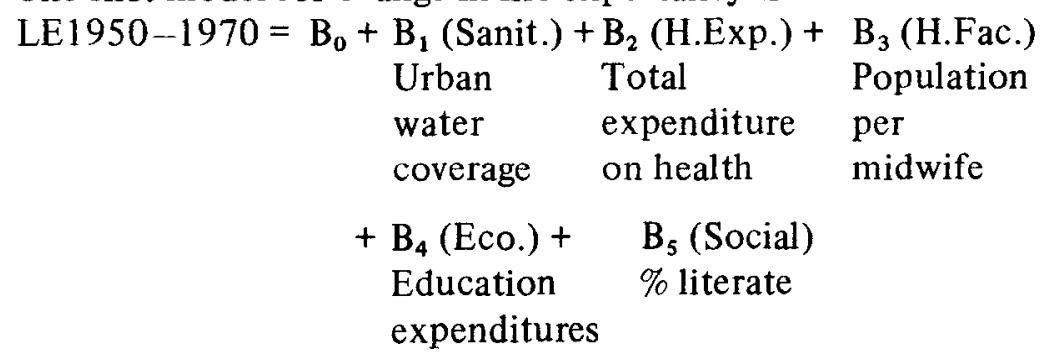
LE1950-1970 $=9.935-\quad 0.000014$ (Health Facilities) $[0.667,14.90][0.000004,-3.04]$
$\mathrm{n}=26$
$\mathrm{R}^{2}$ at first step (population per midwife) $=0.28$
$(\mathrm{F}=9.24, \mathrm{p}=0.006$, s.e. $=2.97)$

Partial correlations of each of the other four were all less than 0.01 and did not increase the overall amount of variation explained. As was done with level of life expectancy, subsequent analyses were performed to expand the number of countries included as much as possible. By taking the weaker health personnel variable, population per physician, the sample size is increased to 53 and the following results are obtained:

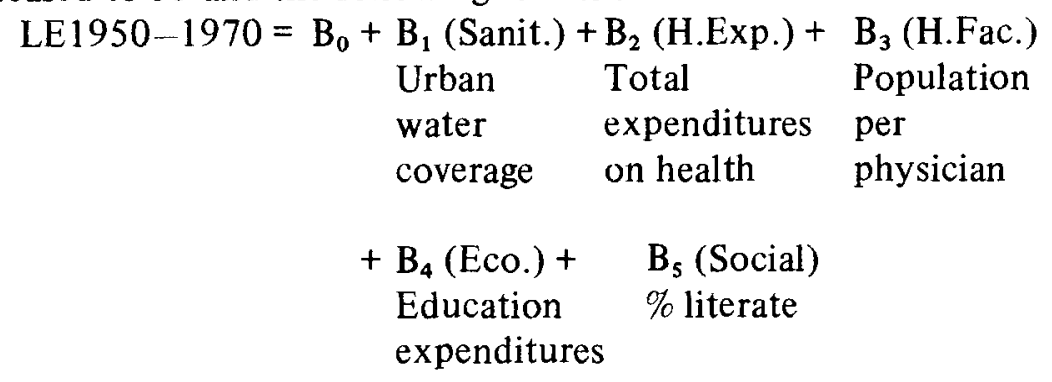
LE $1950-1970=6.205+0.040$ (Sanitation)
$[1.35,4.59][0.017,2.39]$

$\mathrm{n}=53$

$\mathrm{R}^{2}$ at first step (\% total urban water coverage) $=0.10$

$(F=5.72, \mathrm{p}=0.021$, s.e. $=2.76)$ 
Again, partial correlations of each of the health expenditure, health facilities, economic, and social variables were all under 0.01 and not significant. It is interesting, however, that the next most significant variable amongst the remaining four would have been population per midwife.

In conclusion, for the analysis looking at changes in life expectancy over time, economic indicators, health expenditures, and social indicators play less of a role in terms of showing correlation in this multivariate model. The primary indicators seem to be low level health technology (population per midwife) or levels of sanitation (urban water coverage).

\section{LEVELS OF INFANT MORTALITY}

In the multivariate analysis of levels of infant mortality the social indicator variables, specifically percent of population literate, dominated as the chief determinant. While no direct causal link can be proven by this high association, it is certainly plausible that the various forms of communication, of which literacy levels may be a surrogate, are playing a role here.

The regression equation resulting from this stepwise linear regression process is:

\begin{tabular}{|c|c|c|c|}
\hline IMR1974 = & $\begin{aligned} \mathbf{B}_{0}+ & \mathbf{B}_{1} \text { (Sanit.) }+ \\
& \text { Per capita } \\
& \text { electrical } \\
& \text { consumption }\end{aligned}$ & $\begin{array}{l}B_{2} \text { (H.Exp.) }+ \\
\text { Pharma- } \\
\text { ceutical } \\
\text { imports }\end{array}$ & $\begin{array}{l}\text { B }_{3} \text { (H.Fac.) } \\
\text { Population } \\
\text { per } \\
\text { physician }\end{array}$ \\
\hline & $\begin{array}{l}+\mathrm{B}_{4}(\text { Eco. })+ \\
\quad \% \text { labor } \\
\text { force in } \\
\text { agriculture }\end{array}$ & $\begin{array}{l}\mathrm{B}_{5} \text { (Social) } \\
\% \text { literate }\end{array}$ & \\
\hline
\end{tabular}

$$
\begin{array}{rll}
\text { IMR1974 }= & 170.24- & 1.355(\text { Social Indicator) } \\
& {[6.61,25.75]} & {[0.124,-10.96]}
\end{array}
$$

$\mathrm{n}=42$

$\mathrm{R}^{2}$ at first step (\% literate) $=0.75$

$(\mathrm{F}=120.23, \mathrm{p}=0.000$, s.e. $=21.96)$

The other independent variables did not add to the $75 \%$ variation already explained by literacy level. These results very strongly support the notion that communication and education activities do have an influence on the level of well-being in a region. Though the findings show literacy dominates in the multivariate model, the high associations between IMR and other communication surrogates such as radios per 1,000 population also suggest 


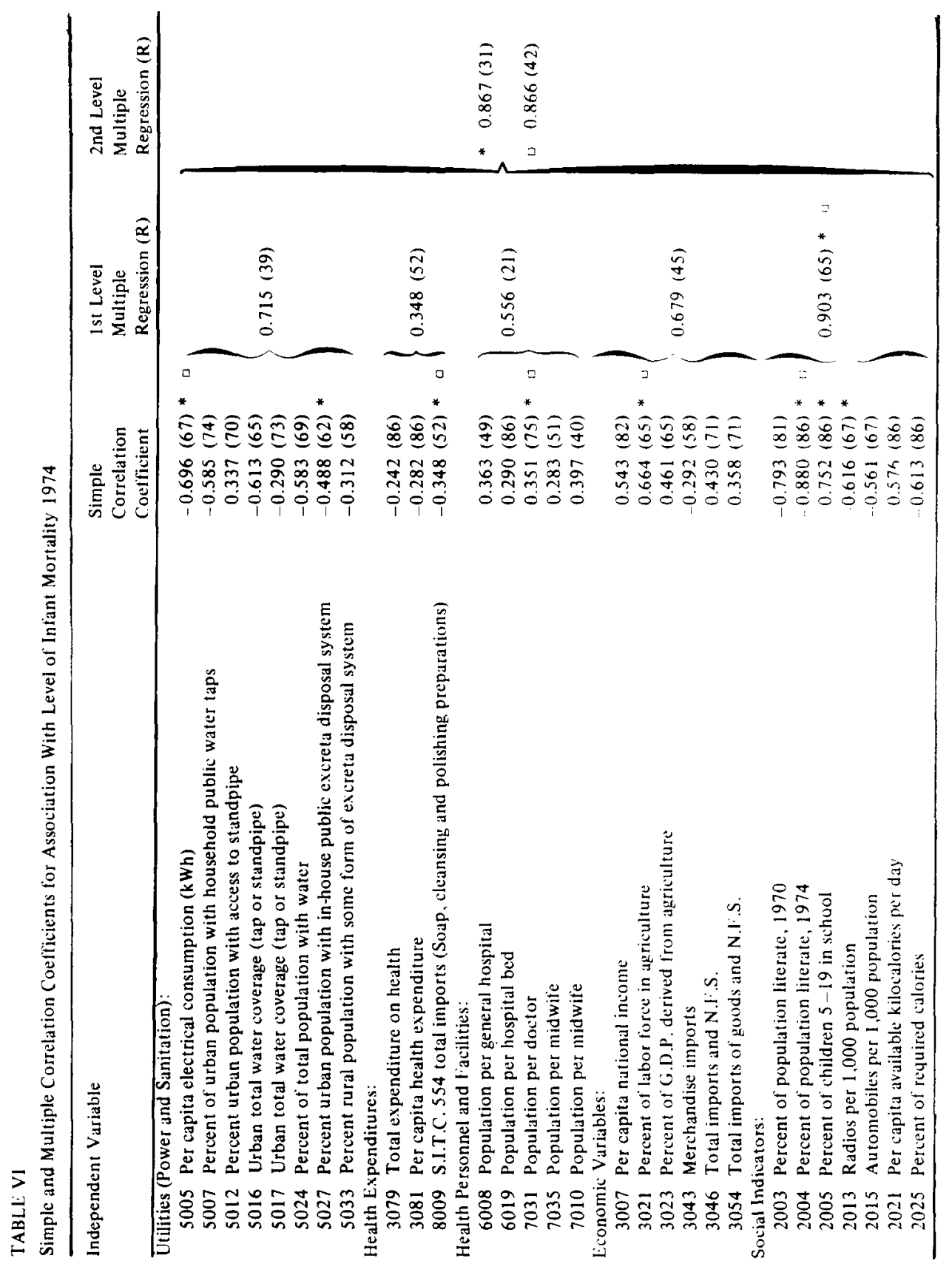


that the communication process broadly has an influence on the health behavior of populations.

Female literacy has been shown in other studies to be highly correlated with childhood mortality, so the present results are consistent with explanations. Some of the causal links hypothesized between literacy and childhood mortality are:

(1) Increased awareness of personal hygiene;

(2) The propensity of the literate to seek medical care from scientific rather than from folk sources;

(3) Cognitive development enabling the consequences of particular acts to be anticipated, particularly those associated with child care; and

(4) Greater efficiency in consumption. That is, the literate pay lower prices for the goods and services they purchase and thus secure more goods and services from a fixed amount of income (Sloan, 1971).

\section{Discussion and Conclusions}

The problem of determining what "explains" mortality and changes in mortality is similar in concept to determining the production function of an industrial or agricultural product. That is, many inputs, resources, and environmental conditions are necessary. At any given level of output, all of the factors of production make contributions. The question of whether to increase the use of some or decrease the use of others is answered by testing the effects on changes in output of small changes in one or another of the inputs. It is essential to keep in mind that the marginal productivity of any input is related closely to the simultaneous utilization of other factors as well. The relative costs of inputs are significant considerations which must be looked at in relation to outputs as well as the physical relationships. Thus there is a "technical production function" and relative prices of inputs to be considered. In our current work we have sought the "social production functions" that relate actions in society to the desired outputs, in this case represented by gains in life expectancy.

The limited explanatory power of income per capita and its weakening strength have been noted by many writers such as Stolnitz, Preston, and Arriaga and Davis. Most of them asserted that the changes in society which were affecting mortality favorably were disease control programs, medical technology, and the like. While our calculations support the idea that income per capita explains only a fraction of life expectancy variations and is lessening in power (in our data from 1960 to 1970; Preston showed this for 1930 to 1960; Arriaga and Davis saw a turning point in Latin America in the 1930's), the health inputs measured - expenditures, personnel, and 
facilities - had much less statistical significance in explaining variations in levels of life expectancy. It is the set of social factors, among which adult literacy is the strongest, that explains the largest part of life expectancy variations, with sanitation investments also playing a significant role.

\section{Appendix I: Ninety Developing Countries - Life Expectancy at Three Points in Time and Infant Mortality Rates in 1974}

\begin{tabular}{|c|c|c|c|c|c|}
\hline \multirow[t]{2}{*}{ Country } & \multicolumn{3}{|c|}{ Life Expectancy } & \multirow{2}{*}{$\begin{array}{l}\text { Relative } \\
\text { change in } \\
\text { life expectancy } \\
1950 \text { 's }-1970 \text { 's }\end{array}$} & \multirow{2}{*}{$\begin{array}{l}\text { Infant } \\
\text { mortali } \\
1974\end{array}$} \\
\hline & 1950 's & 1960 's & 1970 's & & \\
\hline \multicolumn{6}{|c|}{ West Africa } \\
\hline Benin & 31.3 & 36.0 & 41.0 & 9.7 & 185.0 \\
\hline Ghana & 34.0 & 39.0 & 43.5 & 9.5 & 133.0 \\
\hline Guinea & 31.3 & 36.0 & 41.0 & 9.7 & 175.0 \\
\hline Ivory Coast & 33.5 & 38.4 & 43.5 & 10.0 & 160.0 \\
\hline Liberia & 34.5 & 38.5 & 43.5 & 9.0 & 159.0 \\
\hline Mali & 33.5 & 36.0 & 38.0 & 4.5 & 168.0 \\
\hline Mauritania & 33.5 & 38.4 & 38.5 & 5.0 & 137.0 \\
\hline Niger & 33.5 & 38.4 & 38.5 & 5.0 & 175.0 \\
\hline Nigeria & 31.3 & 36.0 & 41.0 & 9.7 & 162.0 \\
\hline Senegal & 33.5 & 38.0 & 40.0 & 6.5 & 159.0 \\
\hline Sierra Leone & 33.5 & 38.5 & 43.5 & 10.0 & 136.0 \\
\hline Togo & 31.3 & 36.0 & 41.0 & 9.7 & 127.0 \\
\hline Upper Volta & 31.0 & 34.0 & 38.0 & 7.0 & 180.0 \\
\hline \multicolumn{6}{|c|}{ East Africa } \\
\hline Burundi & 31.3 & 36.0 & 39.0 & 7.7 & 150.0 \\
\hline Ethiopia & 31.0 & 36.5 & 39.0 & 8.0 & 178.0 \\
\hline Kenya & 40.0 & 45.0 & 50.0 & 10.0 & 115.0 \\
\hline Madagascar & 33.5 & 38.4 & 43.5 & 10.0 & 102.0 \\
\hline Malawi & 33.5 & 36.5 & 41.0 & 7.5 & 119.0 \\
\hline Mozambique & 33.5 & 38.5 & 43.5 & 10.0 & 150.0 \\
\hline Rwanda & 33.5 & 38.5 & 41.0 & 7.5 & 133.0 \\
\hline Somalia & 33.5 & 36.8 & 41.0 & 7.5 & 177.0 \\
\hline Rhodesia & 41.8 & 46.8 & 51.5 & 9.7 & 122.0 \\
\hline Uganda & 40.0 & 45.0 & 50.0 & 10.0 & 160.0 \\
\hline Tanzania & 34.2 & 39.2 & 44.5 & 10.3 & 160.0 \\
\hline Zambia & 36.0 & 41.0 & 44.5 & 8.5 & 157.0 \\
\hline \multicolumn{6}{|c|}{ North Africa } \\
\hline Algeria & 43.1 & 48.1 & 53.2 & 10.1 & 126.0 \\
\hline Egypt & 42.4 & 47.4 & 52.4 & 10.0 & 98.0 \\
\hline Libya & 42.9 & 47.9 & 52.9 & 10.0 & 125.0 \\
\hline Morocco & 42.9 & 47.9 & 52.9 & 10.0 & 149.0 \\
\hline Sudan & 38.6 & 43.6 & 48.6 & 10.0 & 136.0 \\
\hline Tunisia & 43.6 & 48.6 & 54.1 & 10.5 & 128.0 \\
\hline
\end{tabular}


(Appendix I cont'd)

Country

\begin{tabular}{llll} 
Life expectancy & & $\begin{array}{l}\text { Relative } \\
\text { change in } \\
\text { life expectancy } \\
1950 \text { 's 1960's }\end{array}$ & $\begin{array}{l}\text { Infant } \\
\text { mortality }\end{array}$ \\
\hline & 1970 's 1970 's & 1974
\end{tabular}

Central Africa

Angola
Central African Empire
Chad
Congo
Cameroon
Zaire
$\quad$ South Africa

Lesotho

30.0

38.5

8.5

200.0

$33.0 \quad 37.0$

41.0

163.0

$31.3 \quad 36.0$

38.5

8.0

160.0

$33.5 \quad 38.4$

43.5

175.0

$33.5 \quad 38.4$

41.0

135.0

$38.5 \quad 40.0$

43.5

7.5

160.0

South Africa

$\begin{array}{llll}35.9 & 40.9 & 46.0 & 10.1\end{array}$

114.0

$44.4 \quad 48.6$

51.5

7.1

117.0

Tropical America

\begin{tabular}{l} 
Bolivia \\
Brazil \\
Colombia \\
Ecuador \\
Paraguay \\
Peru \\
Venezuela \\
\multicolumn{1}{r}{ Middle America }
\end{tabular}

Costa Rica

\section{8}

54.2

43.8

46.8

6.0

108.0

50.2

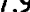

61.4

7.2

82.0

$47.2 \quad 54.2$

60.9

10.7

76.0

$51.5 \quad 57.0$

59.6

12.4

78.0

$44.8 \quad 51.0$

61.9

65.0

54.2

60.2

$55.7 \quad 10.9$

$64.7 \quad 10.5$

110.0

50.0

El Salvador

628

68.2

10.0

52.0

$43.7 \quad 51.5$

57.8

14.1

58.0

41.2

47.2

52.9

11.7

79.0

Honduras

36.9

45.1

53.5

115.0

51.6

59.5

16.6

61.0

Nicaragua

Panama

43.0

47.9

63.2

11.6

121.0

58.8

62.9

52.9

9.9

66.5

44.0

Temperate America

Argentina

Chile

Uruguay

Caribbean

Cuba

Dominican Republic

Haiti

Jamaica

Puerto Rico

East Asia

People's Republic China

Hong Kong

Korea (DR)

Korea (R)
$62.7 \quad 66$.

$54.1 \quad 57.7$

66.3

68.3

68.2

62.6

69.8

5.5

8.5

3.5

60.0

71.0

45.0
$58.8 \quad 65.1$

45.1

40.5

57.9

64.4

53.0

69.8

11.0

12.7

9.5

$45.5 \quad 50.0$

$65.8 \quad 69.5$

69.5

72.1

7.7

45.0

55.5

66.1

55.2

47.5

47.5

55.2
61.6

16.6

70.0

60.6

60.6

9.1

13.1

13.1

29.0

98.0

150.0

26.0

55.0

100.0

47.0 
(Appendix I cont'd)

Country

Life Expectancy

1950's 1960's 1970's

Relative

Infant

change in

mortality

life expectancy

1950's-1970's

1974

Middle Asia

\section{Afghanistan}

30.2

35.3

40.3

10.1

182.0

Bangladesh

36.7

40.8

35.8

$-0.9$

132.0

Inta

31.1

38.1

43.6

12.5

Iran

38.7

49.5

134.0

139.0

$33.1 \quad 38.1$

43.6

152.0

Pakistan

39.1

44.9

49.8

10.5

124.0

Sri Lanka

56.6

63.5

67.8

11.2

45.0

South East Asia

Burma
Kampuchea
Indonesia
Laos
Malaysia
Philippines
Singapore
Viet Nam
Thailand

$40.0 \quad 45.0$

$39.4 \quad 43.4$

50.0

10.0

126.0

$37.5 \quad 42.5$

45.4

6.0

127.0

37.8

47.5

125.0

48.5

40.4

40.4

123.0

46.0

54.2

59.4

2.6

75.0

52.2

58.4

74.0

60.4

65.8

69.5

12.4

17.0

37.8

41.7

44.6

9.1

100.0

45.2

52.5

58.0

6.8
12.8

West Asia

Iraq

42.7

47.7

52.7

10.0

99.0

43.2

48.2

53.2

10.0

97.0

54.0

63.2

59.0

34.7

39.7

45.3

153.0

$\begin{array}{ll}43.8 & 48.8\end{array}$

54.0

93.0

47.0

51.7

56.9

119.0

$\begin{array}{ll}34.7 & 39.7\end{array}$

44.8

152.0

34.7

39.7

44.8

152.0

\section{Appendix II: Five Groups of Independent Variables}

\section{HEALTH EXPENDITURES}

HLTH 65

HLTH 70

HLTH 73

EXHLM\$US

XPCHLT74

SITC541

SITC5411

SITC5413

SITC5414

SITC5415
14 Health expenditure (Million U.S. \$)

77 Health expenditure (Million U.S. \$)

54 Health expenditure (Million U.S. \$)

103 Total expenditure on health (Million U.S. \$)

102 Per capita health expenditure (Million U.S. \$)

1973

1974

1974

72 S.I.T.C. 541 total imports med and pharm products

35 S.I.T.C. 541.1 total imports vitamins

39 S.I.T.C. 541.3 total imports antibiotics

27 S.I.T.C. 541.4 total imports vegetable alkaloids

27 S.I.T.C. 541.5 total imports hormones (insulin, etc.) 
(Appendix II cont'd)

$\begin{array}{lll}\text { SITC5416 } & 50 & \text { S.I.T.C. } 541.6 \text { total imports antiscra, vaccines } \\ \text { SITC5417 } & 68 & \text { S.I.T.C. } 541.7 \text { total imports medicaments } \\ \text { SITC5419 } & 62 & \begin{array}{c}\text { S.I.T.C. } 541.9 \text { total imports pharmaceutical goods } \\ \text { (other than medicaments) }\end{array} \\ \text { SITC554 } & 69 & \begin{array}{l}\text { S.I.T.C. } 554 \text { total imports soap, cleansing and polishing } \\ \text { preparations }\end{array} \\ \text { SITC5541 } & \text { 51 } & \begin{array}{l}\text { S.I.T.C. } 5541 \text { total imports bars soap and soap products } \\ \text { SITC5542 }\end{array} \\ & \text { 56 } & \text { S.I.T.C. } 5542 \text { total imports cleansing agents }\end{array}$

\section{HEALTH FACILITIES AND PERSONNEL}

$\begin{array}{lrlr}\text { TOTBDS60 } & 79 & \text { Total number of hospital beds } & 1960 \\ \text { R HOSP70 } & 36 & \text { Number of rural hospitals } & 1970 \\ \text { POPRH70 } & 36 & \text { Population per rural hospital } & 1970 \\ \text { H CNTR60 } & 23 & \text { Number of health centers } & 1960 \\ \text { POPHCT60 } & 23 & \text { Population per health center } & 1960 \\ \text { H CNTR70 } & 33 & \text { Number of health centers } & 1970 \\ \text { POPHCT70 } & 33 & \text { Population per health center } & 1970 \\ \text { LABTEC A } & 105 & \text { Number of auxiliary health personnel and other } & \\ \text { TRDMWDRA } & 24 & \text { Number of traditional midwives, doctors, etc } & \\ \text { G HOSP60 } & 69 & \text { Number of general hospitals } & 1960 \\ \text { POPGHP60 } & 69 & \text { Population per general hospital } & 1960 \\ \text { G HOSP70 } & 55 & \text { Number of general hospitals } & 1970 \\ \text { POPGHP70 } & 55 & \text { Population per general hospital } & 1970 \\ \text { RHBDS70 } & 33 & \text { Number of rural hospital beds } & 1970 \\ \text { POPRHB70 } & 33 & \text { Population per rural hospital bed } & 1970 \\ \text { HCBDS70 } & 23 & \text { Number of health center beds } & 1970 \\ \text { POPHCB70 } & 23 & \text { Population per health center bed } & 1970 \\ \text { GH13DS60 } & 59 & \text { Number of general hospital beds } & 1960 \\ \text { POPGHB60 } & 58 & \text { Population per general hospital bed } & 1960 \\ \text { GHBDS70 } & 54 & \text { Number of general hospital beds } & 1970 \\ \text { POPGHB70 } & 54 & \text { Population per general hospital bed } & 1970 \\ \text { POPBED74 } & 102 & \text { Population per hospital bed } & 1974 \\ \text { DOCTOR60 } & 93 & \text { Number of doctors } & 1960 \\ \text { POPDR60 } & 92 & \text { Population per doctor } & 1960 \\ \text { DOCTOR70 } & 55 & \text { Number of doctors } & 1970 \\ \text { POPDR70 } & 55 & \text { Population per doctor } & 1970 \\ \text { POPPHYS } & 102 & \text { Population per physician } & 1974 \\ \text { NURSE 60 } & 77 & \text { Number of nurses } & 1960 \\ \text { POPNRS60 } & 77 & \text { Population per nurse } & 1960 \\ \text { NURSE 70 } & 52 & \text { Number of nurses } & 1970 \\ \text { POPNRS70 } & 52 & \text { Population per nurse } & 1970 \\ \text { MIDWIF60 } & 62 & \text { Number of midwives } & 1960 \\ \text { POPMDW60 } & 61 & \text { Population per midwife } & 1960 \\ \text { MIDWIF70 } & 44 & \text { Number of midwives } & 1970 \\ \text { POPMDW70 } & 44 & \text { Population per midwife } & 1970 \\ \text { PHARM 60 } & 61 & \text { Number of pharmacists } & 1960 \\ \text { POPHN60 } & 60 & \text { Population per pharmacist } & 1960 \\ \text { PHARM 70 } & 50 & \text { Number of pharmacists } & 1970 \\ \text { POPPHM70 } & 50 & \text { Population per pharmacist } & 1970 \\ & & & \end{array}$


(Appendix II cont'd)

\section{SANITATION ACTIVITIES AND UTILITIES}

PCWOPC60
PCWOPW70
PCWELEC60
PCWELEC70
ELEC C60
ELEC C70
UWB WH62
UBW WH70
UBW WH75
CUWPW627
CUWPW705
UBW PS62
UBW SP70
UBW SP75
CUWSP627
CUWSP705
UBTOTW62
UBTOTW70
URTOTW75
CUTWW627
CUTWW705
RURACW70
RURACW75
CRWAW705
UANDRW70
UANDRW75
CTOTW705
UBWSWG70

UBWSWG75

CUWSW705

UBTOTS70

UBTOTS75

CUTSG705

RURWSG70

RURWSG75

CRWSG705

URTOTS70

URTOTS75

CURSG705
35 Percent of dwelling units without piped water

30 Percent of dwelling units without piped water

27 Percent of dwellings with electricity

79 Per capita electrical consumption ( $\mathrm{kWh}$ )

81 Per capita electrical consumption (kWh)

1970

1960

1970

1962

1970

1975

1962- 70

1970-75

1962

1970

1975

$1962-70$

1970-75

1962

1970

1975

1962-70

1970-75

1970

1975

1970-75

1970

1975

1970-75

1970

1975

$1970-75$

1970

1975

$1970-75$

1970

1975

1970-75

1970

1975

$1970-75$ 
(Appendix II cont'd)

\section{SOCIAL INDICATORS}

\begin{tabular}{|c|c|c|c|}
\hline PCTLIT40 & 17 & Percent of population literate & 1940 \\
\hline PCTLIT60 & 62 & Percent of population literate & 1960 \\
\hline PCTLIT70 & 85 & Percent of population literate & 1970 \\
\hline PCTLIT7A & 91 & Percent of population literate & 1970 \\
\hline PCTLIT74 & 102 & Percent of population literate & 1974 \\
\hline PCINSCHL & 102 & Percent of children 5-19 in school & 1974 \\
\hline PRSCHL60 & 87 & Primary school enrollment as a percent of children $6-11$ years old & 1960 \\
\hline PRSCHL 70 & 106 & Primary school enrollment as a percent of children $6-11$ years old & 1970 \\
\hline SDSCHL60 & 91 & $\begin{array}{l}\text { Secondary school enrollment as a percent of children } 12-17 \text { years } \\
\text { old }\end{array}$ & 1960 \\
\hline SDSCHL70 & 112 & $\begin{array}{l}\text { Secondary school enrollment as a percent of children 12-17 years } \\
\text { old }\end{array}$ & 1970 \\
\hline NPERRM60 & 45 & Average number of persons per room & 1960 \\
\hline NPERRM70 & 48 & Average number of persons per room & 1970 \\
\hline RADIO 60 & 125 & Radios per 1,000 population & 1960 \\
\hline RADIO 70 & 79 & Radios per 1,000 population & 1970 \\
\hline CARS 60 & 75 & Automobiles per 1,000 population & 1960 \\
\hline CARS 70 & 79 & Automobiles per 1,000 population & 1970 \\
\hline QOFLI76 & 100 & Quality of life index $(0-100)$ & 1976 \\
\hline POLFRI76 & 100 & Political freedom index $(0-100)$ & 1976 \\
\hline CAL 40 & 13 & Per capita available kilocalories per day & 1940 \\
\hline CAL 65 & 86 & Per capita available kilocalories per day & 1965 \\
\hline CAL 70 & 91 & Per capita available kilocalories per day & 1970 \\
\hline CAL 74 & 100 & Per capita available kilocalories per day & 1974 \\
\hline PCTCAL60 & 73 & Percent of required calories & 1960 \\
\hline PCTCAL65 & 86 & Percent of required calories & 1965 \\
\hline PCTCAL70 & 76 & Percent of required calories & 1970 \\
\hline PCTCAL74 & 100 & Percent of required calories & 1974 \\
\hline PROT 60 & 74 & Daily protein consumption in grams & 1960 \\
\hline PROT 65 & 86 & Daily protein consumption in grams & 1965 \\
\hline PROT 70 & 76 & Daily protein consumption in grams & 1970 \\
\hline PCPTA 60 & 41 & Percent of protein from animal and pulses & 1960 \\
\hline PCPTA 70 & 76 & Percent of protein from animal and pulses & 1970 \\
\hline FPPTGR65 & 86 & Food production percent growth rate & 1965 \\
\hline FDPAGR65 & 79 & Food demand per annum growth rate & 1965 \\
\hline GINI60 & 27 & Gini coefficient, early 1960's (1960-63) & \\
\hline PCI 2060 & 27 & Percent of income held by bottom 20 percent & \\
\hline PCI 9060 & 27 & Percent of income held by top 10 percent & \\
\hline GINI65 & 18 & Gini coefficient, mid-late 1960's (1966-69) & \\
\hline PCI 2065 & 18 & Percent of income held by bottom 20 percent & \\
\hline $\begin{array}{l}\text { PCI } 9065 \\
\text { GINI70 }\end{array}$ & $\begin{array}{l}18 \\
23\end{array}$ & $\begin{array}{l}\text { Percent of income held by top } 10 \text { percent } \\
\text { Gini coefficient, early } 1970 \text { 's }(1970-73)\end{array}$ & \\
\hline PCI 2070 & 23 & Percent of income held by bottom 20 percent & \\
\hline PCI 8070 & 23 & Percent of income held by top 10 percent & \\
\hline PCTI2060 & 33 & Percent of income held by bottom 20 percent & 1960 \\
\hline PCTI2070 & 32 & Percent of income held by bottom 20 percent & 197 \\
\hline
\end{tabular}


(Appendix II cont'd)

\section{ECONOMIC INDICATORS}

\begin{tabular}{|c|c|c|c|}
\hline GDP $50 \$$ & 18 & Gross domestic product at factor cost (Million U.S. \$) & 1950 \\
\hline GDP $55 \$$ & 27 & Gross domestic product at factor cost (Million U.S. \$) & 1955 \\
\hline GDP $60 \$$ & 81 & Gross domestic product at factor cost (Million U.S. \$) & 1960 \\
\hline GDP $65 \$$ & 88 & Gross domestic product at factor cost (Million U.S. \$) & 1965 \\
\hline GDP $70 \$$ & 88 & Gross domestic product at factor cost (Million U.S. \$) & 1970 \\
\hline GDP $73 \$$ & 83 & Gross domestic product at factor cost (Million U.S. \$) & 1973 \\
\hline PCI6070\$ & 68 & Per capita national income (in $1970 \$$ ) & 1960 \\
\hline PCI7070\$ & 120 & Per capita national income (in 1970\$) & 1970 \\
\hline PTI6070\$ & 68 & Percent change in per capita income & $1960-70$ \\
\hline RCI6070\$ & 68 & Real change in per capita income (in $1970 \$$ ) & $1960-70$ \\
\hline RGNP174 & 70 & Real gross national product index (U.S. $=100$ ) & 1974 \\
\hline PCTUNE60 & 31 & Percent of labor force unemployed & 1960 \\
\hline PCTUNE70 & 45 & Percent of labor force unemployed & 1970 \\
\hline PCLFAG60 & 69 & Percent of labor force in agriculture & 1960 \\
\hline PCLFAG70 & 77 & Percent of labor force in agriculture & 1970 \\
\hline PCGDPA60 & 63 & Percent of G.D.P. derived from agriculture & 1960 \\
\hline PCGDPA70 & 80 & Percent of G.D.P. derived from agriculture & 1970 \\
\hline EXEDM\$US & 103 & Total expenditure on education (1) & 1974 \\
\hline XPCED74 & 102 & Per capita education expenditure (1) & 1974 \\
\hline PCGDPA75 & 57 & Percent of G.D.P. derived from agriculture & 1975 \\
\hline ECONTYPE & 108 & Type of economic system & 1976 \\
\hline ACGDP 607 & 32 & Annual growth rate G.D.P. & $1960-70$ \\
\hline PCCGDP67 & 32 & Per capita annual growth rate G.D.P. & $1960-70$ \\
\hline GOVCON67 & 30 & Annual growth rate of government final consumption & $1960-70$ \\
\hline PRICON67 & 30 & Annual growth rate of private final consumption & $1960-70$ \\
\hline GFCAPF 67 & 32 & Annual growth rate of fixed capital formation & $1960-70$ \\
\hline XPORT607 & 26 & Annual growth rate of exports of goods and services & $1960-70$ \\
\hline IPORT607 & 26 & Annual growth rate of imports of goods and services & $1960-70$ \\
\hline ACGDP05 & 36 & Annual growth rate G.D.P. & $1970-75$ \\
\hline PCCGDP05 & 36 & Per capita annual growth rate G.D.P. & $1970-75$ \\
\hline GOVCON05 & 33 & Annual growth rate of government final consumption & $1970-75$ \\
\hline PRICON05 & 32 & Annual growth rate of private final consumption & $1970-75$ \\
\hline GFCAPF05 & 34 & Annual growth rate of exports capital formation & $1970-75$ \\
\hline XPORT705 & 30 & Annual growth rate of exports of goods and services & $1970-75$ \\
\hline IPORT705 & 30 & Annual growth rate of imports of goods and services & $1970-75$ \\
\hline
\end{tabular}

\section{Notes}

1 Variables were taken from data tapes of the World Bank, most of which have been published in World Tables 1976, published for the World Bank by Johns Hopkins University Press (1976); United Nations Statistical Yearbook, 1977, U.N.; World Population Prospects as Assessed in 1973 (1977) U.N.; Population and Vital Statistics Report, Series A, Vol. XXIX, No. 4 (1977) U.N.; World Military and Social Expenditures, 1977, Ruth Leger Sivard, Rockefeller Foundation (1977); Size Distribution of Income, A Compilation of Data, Shail Jain, World Bank (1975); "Real G.N.P. per capita for more than 100 countries," Irving R. Kravis, Alan W. Heston and Robert Summers (1978), The Economic Journal, Vol. 88, Cambridge University Press, June; United Nations Demographic Yearbook (1977), U.N.; Community Water Supply and Wastewater Disposal (1976), MidDecade Progress Report, Director General, World Health Organization, May.

2 [standard error, $t$ ] 


\section{References}

Arriaga, Eduardo E. and Davis, Kingsley (1969). "The patterns of mortality change in Latin America," Demography 6: 223-242.

Fuchs, Victor R. (1979). "Economics, health and post-industrial society," Milbank Memorial Fund Quarterly 7: 153-182.

Gilliand, Pierre and Galland, René (1977). "Outline on international comparison of public health, based on data collected by the World Health Organization," World Health Statistics Report 30: 227-238.

Jain, Shail (1975). Size Distribution of Income, A Compilation of Data. Washington, D.C.: The World Bank.

Kravis, Irving R., Heston, Alan W. and Summers, Robert (1978). "Real G.N.P. per capita for more than 100 countries." Cambridge: The Economic Journal, volume 88.

Krishnan, P. (1975). "Mortality decline in India, 1951-1961: development versus public health program hypothesis," Social Science and Medicine 9: 475-479.

Preston, Samuel H. (1976a). Mortality Patterns in National Populations. New York: Academic Press.

Preston, Samuel H. (1976b). "Causes and consequences of mortality declines in less developed countries during the twentieth century," Conference on Population and Economic Change in Less Developed Countries, September 30-October 2, 1976.

Shuval, Hillel, Tilden, Robert and Grosse, Robert (1979). "The health benefits of sanitation investments: a threshold-saturation theory," Ann Arbor: The University of Michigan School of Public Health.

Sivard, Ruth Leger (1977). World Military and Social Expenditures. New York: The Rockefeller Foundation.

Sloan, Frank (1971). Survival of Progeny in Developing Countries: An Analysis of Evidence from Costa Rica, Mexico, East Pakistan, and Puerto Rico. Santa Monica: Rand Corporation.

Smucker, Celeste (1975). Socio-Economic and Demographic Correlates of Infant and Child Mortality in India. Doctoral Dissertation, The University of Michigan.

Stolnitz, George J. (1975). "International mortality trends: some main facts and implications," United Nations, Department of Economic and Social Affairs, The Population Debate: Dimensions and Perspectives, Papers of the World Conference, Bucharest, 1974, Volume 1. Population Studies 57.

United Nations (1977a). Population and Vital Statistics Report, Series A, Volume XXIX, No. 4 United Nations (1977b). United Nations Demographic Yearbook, 1977.

United Nations (1977c). United Nations Statistical Yearbook, 1977.

United Nations (1977d). World Population Prospects as Assessed in 1973.

World Bank (1976). World Tables 1976. Baltimore: Johns Hopkins University Press.

World Health Organization (1976). Community Water Supply and Wastewater Disposal, Mid-Decade Progress Report, Director General, World Health Organization.

\section{Acknowledgements}

The help of Mr. Robert Eckstein and Mr. Robert Tilden, researchers at The University of Michigan School of Public Health, with the extensive data collection and their assistance in producing the graphs is gratefully acknowledged. 